A CHOICE OF

THOMAS HARDY'S POEMS 


\title{
A CHOICE OF THOMAS HARDY'S POEMS
}

\author{
Made by \\ GEOFFREY GRIGSON \\ Illustrated by \\ Glynn Thomas
}




\title{
Introduction () Geoffrey Grigson 1969 \\ Illustrations (c) Macmillan and Co Ltd 1969
}

Softcover reprint of the hardcover 1st edition 1969 978-0-333-10009-7

\author{
First published 1969 by \\ MACMILLAN AND CO LTD \\ Little Essex Street London wC2 \\ and also at Bombay Calcutta and Madras \\ Macmillan South Africa (Publishers) Pty Ltd Fohannesburg \\ The Macmillan Company of Australia Pty Ltd Melbourne \\ The Macmillan Company of Canada Ltd Toronto \\ Gill and Macmillan Ltd Dublin
}

ISBN 978-1-349-00671-7 ISBN 978-1-349-00669-4 (eBook)

DOI 10.1007/978-1-349-00669-4 


\section{CONTENTS}

Introduction

The Night of Trafalgár

Shortening Days at the Homestead 20

The Oxen 2 I

To the Moon $\quad 22$

The Roman Road 23

Friends Beyond $\quad 24$

A Bird-Scene at a Rural Dwelling $\quad 26$

A Church Romance $\quad 27$

A Sheep Fair $\quad 28$

A Broken Appointment $\quad 29$

At Casterbridge Fair: The Ballad-Singer 30

'Regret Not Me' 3 I

In Time of 'The Breaking of Nations' 33

A Trampwoman's Tragedy 34

'When I set Out for Lyonnesse' 39

'A Man was Drawing Near to Me' 40

At the Word 'Farewell'

A Thunderstorm in Town 44

Where They Lived 45

'And There was a Great Calm' $\quad 46$

On Sturminster Foot-Bridge $\quad 48$

At a Country Fair $\quad 49$

At the Railway Station, Upway 50

No Buyers $\quad 5^{\mathbf{I}}$

Snow in the Suburbs $\quad 52$

To an Unborn Pauper Child 53

The Self-Unseeing $\quad 55$

Throwing a Tree $\quad 56$

Overlooking the River Stour $\quad 57$

An August Midnight $\quad 58$ 
Lausanne: In Gibbon's Old Garden $\quad 59$

The Darkling Thrush 60

Waiting Both $\quad 62$

Lying Awake $\quad 62$

Afternoon Service at Mellstock $\quad 63$

Nobody Comes $\quad 64$

The Harbour Bridge $\quad 65$

Life and Death at Sunrise $\quad 67$

The Five Students $\quad 68$

The Mock Wife $\quad 70$

Once at Swanage $\quad 72$

Night-Time in Mid-Fall $\quad 73$

During Wind and Rain 74

Drawing Details in an Old Church $\quad 75$

$\begin{array}{ll}\text { The Voice } & 76\end{array}$

After a Journey $\quad 77$

The Phantom Horsewoman $\quad 79$

'If You Had Known' 8I

Where the Picnic Was $\quad 82$

Days to Recollect $\quad 83$

'I Said to Love'

The Garden Seat $\quad 85$

A Light Snow-Fall after Frost 86

In Sherborne Abbey $\quad 87$

He Never Expected Much $\quad 89$

'I Travel as a Phantom Now'

Afterwards 91

Surview $\quad 92$

Index to First Lines $\quad 94$ 
A CHOICE OF

THOMAS HARDY'S POEMS 